\title{
Використання Хондроцерину у комплексному лікуванні остеоартрозу великих суглобів нижніх кінцівок у спортсменів
}

\author{
Г. І. Герцен, Р. М. Остапчук, М. О. Мікеладзе, \\ Л. Д. Амілахварі
}

Національна медична академія післядипломної освіти ім. П. Л. Шупика, Київ, Україна

\begin{abstract}
Резюме. В работе представлены результаты комплексного лечения 36 пациентов с остеоартрозом тазобедренного и коленного суставов. В отличие от пациентов первой группы, пациенты второй группы дополнительно получали Хондроцерин на протяжении 3-4 мес. Результаты клинико-лабораторных исследований показали, что если в первые дни лечения не отмечено разницы терапевтического эффекта между двумя группами пациентов, то в дальнейшем на протяжении 3-4 нед. и до 4-5 мес. исследования наблюдалось явное последействие препарата, сопровождающееся более выраженным купированием боли и улучшением статико-динамической функции конечности.

Ключевые слова: спортсмены, остеоартроз, Хондроцерин.
\end{abstract}

\begin{abstract}
Summary. The results of complex conservative treatment provided over 36 sportsmen with hip and knee joint osteoarthrosis are introduced in a report. Unlike the patient of the first group, the patient of the second group had been taking hondrocerin additionally during 3-4 month. The results of clinic-laboratory analysis show the following: if there was no big difference in therapeutic efficiency between two patient groups during the first days after treatment after 3-4 weeks and 4-5 month later obvious medicine consequences were shown by the means of pain relief and better staticdynamic extremity function.
\end{abstract}

Keywords: the sportsmen, osteoarthrosis, Hondrocerin.

Постановка проблеми. Остеоартроз (ОА) на сьогодні входить до числа найпоширеніших захворювань суглобів, що призводить до інвалідизуючої симптоматики орієнтовно у $8 \%$ спортсменів високої кваліфрікації. В останніх ризик втрати працездатності на грунті ОА великих суглобів нижніх кінцівок так само великий, як при серцево-судинних захворюваннях, і вищий, ніж за іншої патології $[1,3] .3$ даних ВОЗ про соціальні наслідки захворювань випливає, що серед причин, котрі ведуть до непрацездатності, ОА великих суглобів нижніх кінцівок посідає четверте місце у жінок і восьме - у чоловіків [2, 4]. У всьому світі фрінансові затрати, пов'язані з лікуванням ОА, величезні, що свідчить про поширеність захворювання і систематичність витрат на лікування.

Остеоартроз суглобів нижніх кінцівок характеризується больовим синдромом і функціональною недостатністю (контрактурами, гіпотрофрією м'язів, кульгавістю), в результаті чого настає зниження якості життя пацієнтів, підвищується ризик розвитку супутньої патології. Сучасні концепції лікування ОА включають купірування патологічної симптоматики за допомогою різних методів, у тому числі за допомогою немедикаментозних, медикаментозних і інвазивних. Враховуючи те, що в патогенезі розвитку ОА завжди спостерігаються метаболічні, морфологічні зміни суглобового хряща, що призводять до його хондромаляції, ефективною патогенетичною терапією $\epsilon$ призначення препаратів гіалуронової кислоти - хондроїтинсульфату і глюкозамінсульфату. Препарати чинять як симптом-модифрікуючий, так і структурно-модифрікуючий вплив на суглобовий хрящ $[5,6]$. Останнім часом з'явився новий препарат Хондроцерин (діацереїн), що володіє такими самими властивостями. Він характеризується як хондропротектор, аналгетик і протизапальний препарат, механізм протизапальної дії не зумовлений впливом на ЦОГ та ліпооксигеназу. Препарат інгібує продукцію ІЛ-1 макрофрагами та синовіоцитами, пригнічує продукцію мієлопероксидази, бета-глюкоронідази та еластази, зменшує вміст металопротеїназ у хрящі, стимулює синтез протеогліканів, глюкозаміногліканів і гіалуронової кислоти [5, 7].

Мета дослідження: із урахуванням комбінованого (хондропротекторного, знеболювального, 
протизапального) механізму дії Хондроцерину вивчити його ефрективність у лікуванні спортсменів з ОА великих суглобів нижніх кінцівок.

Матеріали і методи дослідження. У ході клініко-лабораторних досліджень було обстежено 36 спортсменів з ОА кульшового і колінного суглобів, які протягом 2008-2012 рр. знаходились під наглядом у клініках кафедри ортопедії і травматології № 1 Національної медичної академії післядипломної освіти ім. П. Л. Шупика. Вік пацієнтів 28-42 роки, з них сім жінок і 29 чоловіків. За важкістю ураження суглобів ОА I-II ступеня мав місце у 28 пацієнтів, III-IV ступеня - у восьми. Якщо при ОА I-II ступеня консервативне лікування проводили відповідно до загальноприйнятих показань, то при AO III-IV ступеня - через протипоказання до оперативного лікування або відстрочене його виконання. Основна клінічна симптоматика патологічного процесу характеризувалась наявністю болю в ділянці уражених суглобів, інтенсивність і тривалість якої залежали від тяжкості хвороби, наявності або відсутності синовіту, контрактур, кульгавості. У всіх пацієнтів визначалася різного ступеня рентгенологічна симптоматика: зниження висоти щілини суглоба, субхондральний склероз, крайові кісткові розростання. При необхідності додатково виконували комп'ютерну томографрію, магнітнорезонансну томографрію, сонографрію, діагностичну артроскопію суглобів.

Усіх обстежуваних пацієнтів було розподілено на дві групи. В першу (19 хворих) увійшли пацієнти, які отримали протягом 3-4 тиж. традиційний комплекс консервативної терапії, що включав розвантаження ураженого суглоба, ортопедичні устілки, манжетне витягнення, НПЗП, біостимулятори, засоби, які нормалізують мікроциркуляцію, фрізіотерапію (магніто- або ампліпульсотерапію), масаж, лікувальну фрізкультуру. В другій групі (17 хворих) крім зазначеного курсу терапії додатково призначали Хондроцерин по одній капсулі (50 мг) двічі на добу під час їди протягом 3-4 міс. Тому більшість пацієнтів цієї групи продовжували прийом препарату після виписки зі стаціонару.

Нами проведено оцінку найближчих і віддалених результатів комплексного консервативного лікування пацієнтів з ОА кульшового і колінного суглобів. Для цього пацієнтів обстежено як у стаціонарі, так і після виписки на контрольних оглядах до чотирьох місяців. При цьому у пацієнтів до початку лікування і після нього досліджували інтенсивність больового синдрому за шкалою ВАШ, враховували сумарний показник виразності больових відчуттів (у спокої, вдень, вночі, «стартовий біль», біль при пальпації, біль у суглобах під час руху), а також відмічали наявність вирівнювання контуру суглобів, синовіту, напруження м'язів, контрактур. Амплітуду рухів у кульшовому суглобі досліджували в сагітальній, фронтальній і горизонтальній площинах, у колінному суглобі - в сагітальній площині. У всіх пацієнтів, які знаходилися під наглядом, досліджували наявність гіперемії шкірних покривів, підвищення місцевої температури, визначали тривалість відновлення функціональних порушень, із лабораторних методів - ШОЕ, кількість лейкоцитів, білки, білкові фракції, С-реактивний протеїн. Клінічний ефеект оцінювали за купіруванням або зменшенням больового синдрому, збільшенням амплітуди активних рухів у суглобах, відновленням опороспроможності кінцівки, динаміки лабораторних показників, соціальної i профресійної реабілітації пацієнтів.

Кількісні критерії зміни болю в суглобі за шкалою ВАШ і амплітуди рухів оцінювали статистично за допомогою комп'ютерних прикладних програм «STATISTICA», «Microsoft Excell 2000 ». Між окремими групами показників достовірність відмінностей визначали за допомогою параметричних методів відмінності на основі розрахунку критерію Стьюдента.

Результати дослідження та їх обговорення. Результати проведених клініко-лабораторних обстежень спортсменів обох груп з ОА кульшових і колінних суглобів показали, що на фоні комплексної консервативної терапії уже через три-чотири дні відмічено виражене купірування больового синдрому в балах за шкалою ВАШ (табл.1).

При цьому не відмічено достовірної розбіжності в зниженні больової реакції як у спокої, так і при фрізичному навантаженні між обома групами пацієнтів. Ще більш виражене зниження болю в ділянці уражених суглобів проявлялося до 2128 днів спостереження, особливо у пацієнтів другої групи, які додатково приймали Хондроцерин. Так, у пацієнтів першої групи інтенсивність болю в ділянці кульшового суглоба становила $3,3 \pm 0,21$ бала, колінного суглоба $-3,6 \pm 0,12$ бала, тоді як у пацієнтів другої групи в ділянці кульшового суглоба - 1,9 \pm 0,18 бала, колінного суглоба 1,7 \pm 0,11 бала. Позитивний вплив Хондроцерину дозволив у більшості хворих другої групи знизити або взагалі відмінити НПЗП. Через два-три і чотири-п'ять місяців у пацієнтів першої групи відмічено статистично достовірне зростання болю в ділянці уражених суглобів, що наприкінці спостереження підвищувався в кульшовому суглобі до $6,9 \pm 0,34$ бала, а в колінному - до 6,4 $\pm 0,36$ 
ТАБЛИЦЯ 1 - Інтенсивність болю в уражених суглобах у пацієнтів з остеоартрозом при комплексній консервативній терапії

\begin{tabular}{|l|c|c|c|c|}
\hline \multirow{2}{*}{$\begin{array}{c}\text { Термін } \\
\text { спостереження }\end{array}$} & \multicolumn{2}{|c|}{ Кульшовий суглоб } & \multicolumn{2}{|c|}{ Колінний суглоб } \\
\cline { 2 - 5 } & I група & II група & I група & II група \\
\hline До лікування & $7,7 \pm 0,62$ & $7,8 \pm 0,71$ & $7,9 \pm 0,64$ & $7,8 \pm 0,73$ \\
\hline $\begin{array}{l}\text { Через три- } \\
\text { чотири дні }\end{array}$ & $3,5 \pm 0,48$ & $3,3 \pm 0,29$ & $3,0 \pm 0,31$ & $2,9 \pm 0,3$ \\
\hline $\begin{array}{l}\text { Через 21-28 } \\
\text { днів }\end{array}$ & $3,3 \pm 0,21$ & $1,9 \pm 0,18$ & $3,6 \pm 0,12$ & $1,7 \pm 0,11$ \\
\hline $\begin{array}{l}\text { Через два-три } \\
\text { місяці }\end{array}$ & $4,3 \pm 0,26$ & $2,3 \pm 0,17$ & $4,4 \pm 0,22$ & $1,8 \pm 0,13$ \\
\hline $\begin{array}{l}\text { Через чотири- } \\
\text { п'ять місяців }\end{array}$ & $6,9 \pm 0,34$ & $4,4 \pm 0,2$ & $6,4 \pm 0,36$ & $4,1 \pm 0,22$ \\
\hline
\end{tabular}

бала. У цей самий час у пацієнтів другої групи, у яких лікування було доповнене Хондроцерином, мало місце менш виражене підвищення больової реакції, що достовірно зростала лише наприкінці дослідження (через чотири-п'ять місяців) до 4,4 $\pm 0,2$ бала в ділянці кульшового суглоба і до $4,1 \pm 0,22$ бала в ділянці колінного суглоба. При цьому відмінності в ступені вираженості болю за шкалою ВАШ до двох-трьох і чотирьох-п'яти місяців спостереження між обома групами пацієнтів підтверджено статистично.

Що стосується амплітуди рухів у кульшовому і колінному суглобах, у пацієнтів обох груп на фоні комплексної терапії отримано наступні дані (табл. 2).

До трьох-чотирьох днів від моменту початку лікування і особливо до $21-28$ днів в обох групах пацієнтів відмічено статистично достовірне відновлення амплітуди рухів у суглобах. Так, до 21-28 днів вона в кульшовому і колінному суглобах у пацієнтів обох груп була відновлена порівняно з вихідним рівнем (від 76,3 $\pm 6,48$ до $81,5 \pm 8,34 \%)$. Відмічено статистично достовірні відмінності в ступені відновлення рухів у суглобах між двома групами пацієнтів: у першій

ТАБЛИЦЯ 2 - Амплітуда рухів у суглобах у пацієнтів 3 остеоартрозом у динаміці комплексної консервативної терапії ( \% відносно норми)

\begin{tabular}{|l|c|c|c|c|}
\hline \multirow{2}{*}{$\begin{array}{c}\text { Термін } \\
\text { спостереження }\end{array}$} & \multicolumn{2}{|c|}{ Кульшовий суглоб } & \multicolumn{2}{|c|}{ Колінний суглоб } \\
\cline { 2 - 5 } & I група & II група & I група & II група \\
\hline До лікування & $76,3 \pm 6,48$ & $78,7 \pm 7,82$ & $81,5 \pm 8,34$ & $80,2 \pm 8,59$ \\
\hline $\begin{array}{l}\text { Через три- } \\
\text { чотири дні }\end{array}$ & $88,9 \pm 7,25$ & $90,1 \pm 8,12$ & $87,9 \pm 7,26$ & $89,7 \pm 7,96$ \\
\hline $\begin{array}{l}\text { Через 21-28 } \\
\text { днів }\end{array}$ & $92,7 \pm 9,57$ & $96,4 \pm 9,58$ & $91,1 \pm 9,71$ & $97,9 \pm 9,53$ \\
\hline $\begin{array}{l}\text { Через два-три } \\
\text { місяці }\end{array}$ & $87,3 \pm 8,72$ & $94,9 \pm 9,71$ & $85,0 \pm 9,49$ & $93,1 \pm 9,51$ \\
\hline $\begin{array}{l}\text { Через чотири- } \\
\text { п'ять місяців }\end{array}$ & $79,3 \pm 7,36$ & $91,4 \pm 9,87$ & $82,4 \pm 8,93$ & $88,3 \pm 8,98$ \\
\hline
\end{tabular}

групі рівень відновлення рухів у кульшовому суглобі становив $92,7 \pm 9,57 \%$, у колінному суглобі $-91,1 \pm 9,71 \%$ відповідно до норми, а у другій групі - відповідно 96,4 $\pm 9,58 \%$ i $97,9 \pm 9,53 \%$.

Після завершення курсу комплексного лікування пацієнтів у динаміці наступного спостереження через два-три і чотири-п'ять місяців відмічено деяке зменшення амплітуди рухів у згаданих суглобах переважно у пацієнтів 3 III-IV ступенем ОА. Така тенденція більшою мірою стосувалась пацієнтів першої групи, у яких амплітуда рухів до 4-5 міс. становила відповідно 79,3 $\pm 7,36 \%$ і $82,4 \pm 8,93 \%$. У пацієнтів другої групи, які додатково приймали Хондроцерин, відмічено менш суттєве зниження амплітуди рухів: $91,4 \pm 9,87 \%$ і 88,3 $\pm 8,98 \%$. Статистично до чотирьох-п'яти місяців підтверджено достовірну різницю в ступені обмеження амплітуди рухів між пацієнтами обох груп.

У більшості пацієнтів другої групи, які у ході лікування додатково приймали Хондроцерин, під час клінічних спостережень були відсутні побічні реакції і порушення лабораторних показників. У двох хворих (10 \%) мали місце діарея і гастралгія, котрі припинилися в ході лікування.

Таким чином, проведені клініко-лабораторні дослідження ефективності Хондроцерину в комплексі лікування спортсменів з ОА кульшового і колінного суглобів показали, що цей препарат має виражений аналгетичний та протизапальний ефект, а також ефект пролонгації досягнутого терапевтичного результату, так званий «ефект післядії», встановлений протягом чотирьох-п'яти місяців спостереження. Так само його відмічено при лікуванні ОА великих суглобів і в інших дослідженнях [9]. Слід зазначити, що цей ефект пов'язаний зі структурно-модифікуючим впливом на суглобовий хрящ, а саме з інгібіцією синтезу прозапального інтерлейкіну-1, який відіграє важливу роль у запаленні, апоптозі хондроцитів, деградації хряща, патогенезі розвитку остеоартрозу $[8,9]$.

\section{Висновки.}

У спортсменів з остеоартрозом кульшового і колінного суглобів Хондроцерин, будучи повільно діючим препаратом, у перші два дні застосування не впливає на лікувальний ефект комплексної консервативної терапії, яка включає НПЗП, біостимулятори, лікувальну фрізкультуру, масаж, фрізіотерапію й ортопедичні методи, проте значно підвищує ефективність комплексного лікування через три-чотири тижні за рахунок аналгетичної і протизапальної дії, дозволяє знизити дози НПЗП. 
У подальші терміни (від одного до чотирьох місяців) достовірно встановлено, що Хондроцерин, маючи аналгетичні та протизапальні властивості, суттєво продовжує

\section{Література}

1. Герцен Г. І. Деформуючий артроз великих суглобів / Герцен Г. І., Остапчук Р. М., Буштрук А. М. // Укр. мед. часопис. - 2003. - № 5(37). - С. 55-68.

2. ЛікуВання остеоартрозу: пірамідний підхід / [Корпан М. І., Чекман І. С., Бур'янов О. А. та ін.]. // Літопис травматол. та ортопед. - 2008. - № 1-2. - С. 47-52.

3. Соßременные способы лечения остеоартроза / [Айвазян В. П., Вардеварян В. В., Манасян М. М. и др.] // Матеріали наук.-практ. конф., присвяченої 90-річчю ДУ «Інститут травматології та ортопедії АМН України. - К., 2009. - C. 18-19.

4. Mazieres B. Molecular markers of cartilage breakdown and synovitis at baseline as predictors of structural progression of hip osteoarthritis. The ECHODIAH Cohort / B. Mazieres, P. Garnero, A. Gueguen, M. Abbal // Ann. Rheum. Dis. 2006. - V. 65, N3. - P. 354-359.

5. Rintelen B. A meta-analysis of controlled clinical studies with diacerein in the treatment of osteoarthritis/ B. Rintelen, K. Neumann, B. Leeb // Arch. Intern. Med. 2006. - № 166 (17). - P. 1899-1906.

6 . The efficacy and safety of diacerein in the treatment of painful osteoarthritis of the knee: a randomized multicenter, double-blind, placebo-controlled study with primary and point at two months after the end of a three-months treatment period / K. Pavelka, K. Karpas, P. Vitek, M. Sedlakova // Arthritis Rheum. - 2007. - V. 56, N12. - P. 4055-4064.

7. Zheng $W$. $Y$. Evaluation of efficacy and safety of diacerein in knee osteoarthritis in Chinese patients / [W. Y. Zheng, F. L. Tang, J. Li et al. // Chin. Med. Sci. J. -2006 . - № 21 (2). - P. 75-80. досягнутий терапевтичний ефект без прийому НПЗП. Така післядія, напевно, обумовлена патогенетичною структурно-модифрікуючою дією препарату на суглобовий хрящ.

\section{References}

1. Hertsen G. I. Deforming arthrosis of large joints / Hertsen G. I., Ostapchuk R. M., Bushtruk A. M. / / Ukrainskyi medychnyi chasopys. - 2003. - № 5 (37). - P. 55-68.

2. Treatment of osteoarthritis: pyramidal approach / [Korpan M. I., Chekman I. S., Burianov O. A. et al.]. / / Litopys travmatologii i ortopedii. - 2008. - № 1-2. - P. 47-52.

3. Modern methods of treatment for osteoarthritis / [Aivazian V. P., Vardevarian V. V., Manasian M. M. et al.] // Materials of scientific and practical. conf. dedicated to the 90th anniversary of «Institute of Traumatology and Orthopedics Academy of Medical Sciences of Ukraine. - Kyiv, 2009. - P. 18-19.

4. Mazieres B. Molecular markers of cartilage breakdown and synovitis at baseline as predictors of structural progression of hip osteoarthritis. The ECHODIAH Cohort / B. Mazieres, P. Garnero, A. Gueguen, M. Abbal // Ann. Rheum. Dis. 2006. - V. 65, N3. - P. 354-359.

5. Rintelen B. A meta-analysis of controlled clinical studies with diacerein in the treatment of osteoarthritis / B. Rintelen, K. Neumann, B. Leeb // Arch. Intern. Med. 2006. - V. 166, N 17. - P. 1899-1906.

6. The efficacy and safety of diacerein in the treatment of painful osteoarthritis of the knee: a randomized multicenter, double-blind, placebo-controlled study with primary and point at two months after the end of a three-months treatment period / K. Pavelka, K. Karpas, P. Vitek, M. Sedlakova // Arthritis Rheum. - 2007. - V. 56, N12. - P. 4055-4064.

7. Zheng $W$. $Y$. Evaluation of efficacy and safety of diacerein in knee osteoarthritis in Chinese patients / [W. Y. Zheng, F. L. Tang, J. Li et al. // Chin. Med. Sci. J. 2006. - V. 21, N2. - P. 75-80. 